\title{
EFEK PENGGUNAAN SMARTPHONE BERKELANJUTAN DI MASA PANDEMI COVID-19 TERHADAP PERKEMBANGAN PSIKOLOGIS ANAK
}

\author{
Muhammad Sufyan As-Tsauri ${ }^{1}$, Bambang Samsul Arifin², ${ }^{2}$ Tarsono ${ }^{3}$ \\ UIN Sunan Gunung Djati Bandung \\ e-mail: ${ }^{1}$ sufyancrb@gmail.com, $\underline{\text { bambangsamsul@uinsgd.ac.id }{ }^{2}}$ 3tarsono@uinsgd.ac.id
}

Diterima: 14 April 2021 I Direvisi: 9 Mei 2021 I Disetujui: 20 Mei 2021 (C) 2021 Pendidikan Guru Madrasah Ibtidaiyah Fakultas Agama Islam Universitas Islam Malang

\begin{abstract}
Abstrak
Penggunaan smartphone berkelanjutan di masa pandemi Covid-19 memiliki dampak terhadap perkembangan psikologis anak dari aspek emosional, sosial dan moral. Penelitian ini juga menelaah empat aspek penting yaitu kepemilikan smartphone, pengawasan orang tua, intensitas penggunaan, dan akibat yang muncul dari penggunaan smartphone tersebut. Penelitian ini penting dikaji akibat dari adanya perpanjangan masa belajar online yang berdampak pada bertambahnya intensitas anak dalam menggunakan smartphone, sehingga efek yang muncul bisa menjadi bahan pertimbangan bagi orang tua dan guru dalam mengawasi tumbuh dan kembang anak. Penelitian ini menggunakan pendekatan kualitatif jenis studi kasus. Teknik pengumpulan data dilakukan dengan cara wawancara, observasi, dan studi dokumen. Hasil penelitian menunjukkan bahwa penggunaan smartphone berkelanjutan berdampak positif dan negatif pada perkembangan psikologis anak. Dampak positif yang muncul berkenaan dengan aspek sosial yaitu tetap berkomunikasi dengan teman-temannya meskipun dalam masa pandemi Covid-19. Adapun dampak negatif yang muncul khususnya pada anak yang menggunakan smartphone lebih dari 2 jam sehari dan tanpa pengawasan orang tua yaitu berkenaan dengan aspek emosional dan sosial anak seperti anak menjadi malas belajar, mudah marah, meniru perilaku yang tidak berfaerah serta menggunakan sebagaian besar waktu untuk bermain game online.
\end{abstract}

Kata kunci: smartphone, pandemi Covid-19, psikologis anak

\begin{abstract}
Continued use of smartphones during the Covid-19 pandemic has an impact on children's psychological development from emotional, social and moral aspects. Study aims to determine the effect of continuous smartphone use during the Covid-19 pandemic on children's psychological development. This study examines four important aspects, namely smartphone ownership, parental supervision, intensity of use, and the consequences of using the smartphone. This research is important to study as a result of the extension of the online learning period which has an impact on the increasing intensity of children using smartphones, so that the effects that arise can be used as consideration for parents and teachers in monitoring children's growth and development. This research uses a qualitative approach to the type of case study. Data collection techniques were carried out by means of interviews, observation, and document study. The results showed that using smartphone continuously had a positive and negative impact on children's psychological development. The positive impact that arises with regard to social aspects is to keep in touch with friends even though during the Covid-19 pandemic. The negative impacts that arise, especially in children who use smartphones for more than 2 hours a day and without parental supervision, are related to emotional
\end{abstract}


Muhammad Sufyan As-Tsauri, Bambang Samsul Arifin, Tarsono

and social aspects of children such as children becoming lazy to learn, irritable, imitating behavior that is not giving away and using most of their time to play online game.

Key words: smartphone, the covid-19 pandemic, child psychology

\section{PENDAHULUAN}

Dunia pada saat ini sedang menghadapi darurat dalam hal kesehatan akibat adanya pandemi Covid-19 yang merupakan sebuah wabah ataupun virus yang saat ini sedang melanda dunia. Penyebaran virus ini terjadi sangat cepat, karena hanya dalam bebrapa bulan virus ini viral di media sosial, hingga saat ini hampir semua negara di dunia telah terkena wabah ini termasuk Indonesia. Munculnya wabah ini secara besar-besaran mempengaruhi seluruh aspek kehidupan di Indonesia, salah satunya keberlangsungan pendidikan. Mempertimbangkan angka positif virus corona terus bertambah setiap hari, akhirnya pemerintah membuat kebijakan proses belajar mengajar dilaksanakan secara online (Ats-Tsauri \& Munastiwi, 2020). Pembelajaran dari akhir Maret 2020 sampai berlanjut di awal tahun 2021 dilaksanakan dirumah sampai batas waktu yang tidak pasti. Pada akhirnya kegiatan belajar mengajar dilaksanakan dengan menerapkan metode daring.

Dengan berubahnya proses pembelajaran dari luar jaringan menuju dalam jaringan akibat virus korona, maka para siswa dipastikan akan sering menggunakan smartphone untuk menunjang proses pembelajaran daring dari rumah. Smartphone adalah alat komunikasi baik jarak dekat maupun jarak jauh (Imam, 2019). Pemakaian smartphone bagi anak pastinya tidak dapat lepas dari peran orangtua sebab pada kenyataannya tidak sedikit orang tua yang sudah menghadirkan smartphone kepada anak terlalu dini (Pradevi, 2020). Dalam hal ini orang tua berperan untuk mengawasi penggunaan smartphone yang dilakukan anak untuk meminimalisir dampak buruk yang dapat ditimbulkan akibat penggunaan smartphone. Selain itu, pemakaian smartphone di masa pandemi secara berlebihan dan tidak digunakan sebagaimana mestinya dapat membuat candu penggunanya. Sebaliknya penggunaan smartphone yang benar di masa pandemi Covid-19 akan melahirkan efek positif pada anak.

Dalam praktiknya hasil penelitian yang dilakukan oleh Suhandi dan Pamela (2020) menyebutkan bahwa anak-anak justru kebanyakan tidak mengikuti instruksi guru untuk belajar dari rumah, mereka lebih memilih menggunakan smartphone untuk menonton youtube, mencari hal-hal yang kurang penting bahkan mereka memilih bermain ke luar rumah sampai lupa waktu (Suhandi \& Pamela, 2020). Pada realitanya, kala anak sudah sangat asyik dengan samrtphonenya, mereka kurang ingat terhadap kewajiban seseorang anak ialah 
belajar serta bersosialisasi dengan benar di kehidupan. Anak-anak cenderung asyik bermain smartphone setiap harinya, baik itu di rumah maupun ketika bermain bersama teman-temannya. Apalagi kanak- kanak lebih asyik dengan gadget daripada mencermati perintah orangtuanya. Tidak hanya itu kerapkali terdapat anak yang marah bila diperintah orangtuanya. Membagikan gadget pada anak tanpa terdapatnya pengawasan orang berusia ataupun orang yang lebih tua memang cenderung memunculkan efek negatif (Syifa, Setianingsih, \& Sulianto, 2019). Karakteristik smartphone yang hanya memberikan komunikasi satu arah yaitu respon dapat memberi dampak pada anak menjadi susah berkomunikasi dan bersosial dengan baik (Sari \& Mitsalia, 2016).

Selain beberapa efek negatif di atas, penggunaan smartphone juga dapat memiliki efek positif, seperti memudahkan anak untuk belajar menulis, membaca, berhitung dan sebagainya. Banyak aplikasi-aplikasi edukatif terlebih game edukatif yang dapat membuat anak terus menjadi pintar. Smartphone digunakan supaya anak tidak sering keluar rumah, sehingga pemakaian smartphone dapat meminimalisir anak terserang virus korona. Anak bisa memahami huruf serta bilangan dan keahlian mengetik, bisa menolong anak yang lemah dalam motorik halus untuk keberfungsian koordinasi antara tangan serta mata yang baik. Mereka bisa menciptakan karya yang bisa dibaca serta ditulis, sehingga bisa membanggakan orang tua (Rozalia, 2017).

Beberapa contoh perubahan perilaku, emosi dan sosial yang terjadi pada anak akibat penggunaan smartphone di atas dapat juga disebut sebagai perkembangan psikologis anak. Dalam perkembangan psikologis anak terdapat tugas-tugas perkembangan yang harus dikuasai anak sesuai dengan jenjang usianya, nilai dan aturan sosial yang harus dipatuhi, memiliki kepribadian yang baik serta menggunakan bahasa yang tepan, sopan dan efisien (Latifa, 2017). Berdasarkan pemaparan masalah dan hasil penelitian terdahulu di atas, maka perlu dilakukan penelitian lebih lanjut terkait dampak kebijakan pemerintah terkait perpanjangan masa belajar online yang mana dalam hal ini meneliti berkenaan dengan "Efek Penggunaan Smartphone Berkelanjutan di Masa Pandemi Covid-19 terhadap Perkembangan Psikologis Anak". Adapun tujuan penelitian ini untuk menganalisis efek penggunaan smartphone berkelanjutan di masa pandemi covid-19 terhadap perkembangan psikologis anak Madrasah Diniyah.

\section{METODE}

Jenis penelitian yang digunakan dalam penelitian ini ialah penelitian kualitatif jenis studi kasus. Penelitian ini dilakukan dari bulan Februari sampai 
Maret 2021 dengan melibatkan 7 siswa yang terdiri dari 3 laki-laki dan 4 perempuan berikut orang tua masing-masing. Peneliti memilih 7 siswa sebagai partisipan penelitian karena mereka adalah pengguna smartphone berkelanjutan dari tahun 2020 ke tahun 2021 masa pandemi Covid-19 akibat dari adanya kebijakan belajar online yang dikeluarkan pemerintah. Seluruh partisipan melakukan kegiatan belajar daring dalam mengikuti Kegiatan Belajar Mengajar (KBM) di sekolah formal baik Sekolah Dasar maupun Madrasah Ibtidaiyyah.

Penelitian ini dilakukan di Madrasah Diniyah Takmiliyyah Awwaliyyah (MDTA) Miftahul Ulum yang berlokasi di Rt. 20 Rw. 03 Desa Bodesari Kecamatan Plumbon Kabupaten Cirebon. Intensitas penggunaan smartphone para siswa meningkat semenjak masa Pandemi Covid-19. Peneliti ingin menelaah pengaruh penggunaan smartphone berkelanjutan di semester 2 pada masa Pandemi Covid19, kaitannya dengan kondisi psikologis siswa saat belajar di kelas sore saat KBM berlangsung di MDTA Miftahul Ulum. Teknik pengambilan data diperoleh dengan cara wawancara, observasi, dan studi dokumen dari hasil penyebaran angket.

Peneliti melakukan wawancara kepada tujuh anak berikut orang tuanya mengenai penggunaan smartphone dan mengobservasi langsung dampak dari pemakaian smartphone di masa pandemi Covid-19 pada saat kegiatan belajar mengajar pada sore hari di sekolah non-formal MDTA Miftahul Ulum. Analisis data dalam pendekatan kualitatif ini meliputi reduksi data, sehingga data yang ingin dicari di lapangan dapat diperoleh. Selanjutnya data yang didapatkan dari proses penelitian dianalisis agar hasil penelitian tidak bersifat subjektif. Pada tahap selanjutnya peneliti menyimpulkan kemudian mengevaluasi hasil penelitian terkait dengan kendala yang ada di dalam penelitian.

\section{HASIL DAN PEMBAHASAN}

Pada bagian ini dibahas efek penggunaan smartphone berkelanjutan di masa pandemi Covid-19 terhadap perkembangan psikologis anak dari empat aspek yaitu 1) kepemilikan smartphone, 2) pengawasan orang tua, 3) intensitas penggunaan smartphone, dan 4) efek yang muncul akibat penggunaan smartphone terhadap psikologis anak. Dari hasil observasi, wawancara, dan penyebaran angket yang peneliti lakukan dapat dipaparkan data sebagai berikut.

\section{Kepemilikan Smartphone}

Hasil pengisian angket orang tua siswa terhadap penggunaan smartphone anak menunjukkan bahwa ada dua anak yang memiliki smartphone sendiri yaitu GA (siswi 11 tahun) dan H (siswa 13 tahun) dan tiga anak yang menggunakan smartphone dengan cara meminjam ke orang tua yaitu F (siswa 9 tahun), NNA 
(siswi 10 tahun), APN (siswi 11 tahun). Kedua anak yang memiliki smartphone sendiri sama-sama menggunakan smartphone tanpa pengawasan orang tua selama masa pandemi Covid-19.

Dari hasil pengamatan peneliti selama KBM 2 bulan di kelas, 3 siswi dan 1 siswa sudah memasuki kelas sebelum bel masuk berbunyi, sementara 1 siswa masih memakan makanan di depan kelas pada saat yang lainnya sudah masuk. Ketika guru menanyakan pelajaran minggu sebelumnya, semua siswa merespon. Seluruh siswa juga menunjukkan ekspresi senang dan tertawa ketika seorang guru bercerita lucu. Hal tersebut dilakukan agar pembelajaran tidak terasa membosankan, monoton dan sebagai tanda bahwa aspek emosi anak dalam keadaan baik (As-Tsauri, 2021). Anak-anak juga mampu menyelesaikan tugas tepat waktu ketika guru memberikan tugas.

\section{Pengawasan Orang Tua}

Dari hasil wawancara peneliti terhadap responden menunjukkan bahwa $\mathrm{H}$ (siswa 13 tahun) dan $\mathrm{N}$ (siswa 1 tahun) menggunakan smartphone tanpa pengawasan orang tua. Selain itu $\mathrm{H}$ dan $\mathrm{N}$ menggunakan smartphone dengan intensitas tinggi setiap harinya selama lebih dari 2 jam. Menurut pengakuan $\mathrm{H}$ bahwa ia menggunakan smartphone sebagian besar waktunya dihabiskan untuk bermain game online selama masa pandemi Covid-19. Namun orangtuanya memberikan batasan waktu dalam penggunaan smartphone yaitu hanya diizinkan sampai pukul 18.00 WIB. Sementara itu N menggunakan smartphone untuk menonton Youtube, Tiktok, dan Instagram dan boleh mengakses kapan saja. Berbeda dengan N, D (siswi 8 tahun) menjelaskan bahwa dia hanya diperbolehkan menggunakan smartphone jika sudah mengerjakan PR dari sekolah.

Dari hasil temuan di atas, sebagian orang tua sudah galat membagikan smartphone kepada anak tanpa mengawasinya. Mereka memberikan hak milik atas smartphone kepada anak tanpa adanya pengawasan dan sebagiannya dilakukan tanpa adanya aturan batas waktu penggunaan. Padahal pengawasan perlu dilakukan oleh orang tua karena akan berdampak pada sikap sosial mereka baik kepada orang tua maupun kepada teman-temannya (Afifulloh, 2019). Secara langsung ataupun tidak langsung, hasil penelitian lain menyebutkan bahwa orang tua menanggung jatah kesalahan dikala anak mereka terlampau sering menghabiskan waktunya dengan smartphone dari pada berhubungan sosial dengan orang lain (Palar, Onibala, \& Oroh, 2018).

Kedudukan keluarga untuk anak di masa pandemi Covid-19 ini sangat berarti. Keluarga, spesialnya orang tua yang mana merupakan cerminan untuk anak berperilaku, berdialog, dan bersosialisasi dengan dunia luar. Disamping itu, 
bersamaan berkembangnya kemajuan teknologi, kedudukan orang tua dalam mengurus serta mendidik anak pula terbantu. Lewat kecanggihan smartphone, orang tua jadi lebih efisien dalam melakukan pendidikan terhadap anak serta membuat anak tidak kerap keluar rumah di masa pandemi Covid-19.

Dalam praktiknya, meskipun masing-masing orang tua memiliki pola asuh yang berbeda, setidaknya penggunaan smartphone yang berlebihan dan tidak dipergunakan sebagaimana mestinya harus dihindarkan. Beberapa strategi yang bisa dilakukan orang tua yang melepas smartphone kepada anak bisa dengan cara 1) menyeting akun gmail yang sama kepada smartphone anak dengan smartphone orang tua, sehingga aktivitas anak terpantau, 2) menentukan waktu khusus untuk anak boleh mengoperasikan smartphone, 3) membatasi durasi pemakaian khususnya pada saat jam malam, sehingga anak tidak malas saat bangun pagi. Hubungan antara peran keluarga untuk menghindari efek negatif pemakaian smartphone pada perilaku ini mendapatkan simpulan yang sama dengan penelitian Markustianto (dalam Palar, 2018) yang menyebutkan bahwa apabila fungsi pengawasan orang tua berjalan baik pada anak, maka perilaku anak dalam mengoperasikan smartphone juga baik. Hal tersebut karena orang tua akan mengarahkan anaknya bagaimana smartphone digunakan dengan baik dan benar. Sebaliknya bila fungsi pengawasaan orang tua tidak dilakukan, maka anak cenderung mengoperasikan smartphone untuk hal-hal yang tidak berfaedah.

\section{Intensitas Penggunaan Smartphone}

Berdasarkan data hasil angket menunjukkan bahwa dua siswa menggunakan smartphone dengan intensitas yang tinggi dalam sehari yaitu pemakaian lebih dari 2 jam. Namun keduanya memiliki perbedaan yaitu $\mathrm{H}$ diberi aturan oleh orang tuanya hanya boleh menggunakan smartphone di siang hari, sementara GA bebas menggunakan kapan saja. $\mathrm{H}$ menggunakan smartphone untuk bermain game sementara GA menggunakan smartphone untuk menonton Youtube dan chatting di Whataps. Penggunaan smartphone memberikan pengaruh bagi kedanya. Efek positif yang muncul yaitu bisa berkomunikasi dengan teman-teman. Perilaku berkomunikasi dengan teman-temannya menunjukkan bahwa anak tersebut matang dalam bersosial dimana anak tetap bergaul dan beradaptasi dengan lingkungan meskipun dalam masa pandemi Covid-19 (Latifa, 2017).

Sementara tiga siswa lainnya yang menggunakan smartphone orang tua mendapatkan pengawaan langsung dari orang tua mereka saat mengoperasikan smartphone. Kedua siswa yaitu NNA dan APN menggunakan smartphone dengan intensitas penggunaan sedang dalam sehari yaitu antara 1 sampai 2 jam, sementara $\mathrm{F}$ menggunakan smartphone dengan intensitas rendah dalam sehari 
yaitu kurang dari 1 jam. Ketiganya terdampak efek baik dan buruk dalam penggunaan smartphone. Efek baik yang muncul dari ketiganya seperti bisa berkomunikasi dengan teman dan digunakan untuk mencari pelajaran. Sementara efek buruk yang muncul seperti anak menjadi gampang marah dan anak sering meniru hal tidak berfaedah dari tayangan yang didapat dari smartphone.

\section{Efek yang Muncul Akibat Penggunaan Smartphone terhadap Psikologis Anak}

Berdasarkan data hasil angket aspek emosional dan moral anak menunjukkan bahwa penggunaan smartphone berkelanjutan memiliki efek negatif yaitu anak menjadi mudah marah dan menjadi malas untuk belajar. Dalam mencapai kematangan emosi, seorang anak perlu bantuan teman dan orang tua untuk mendengarkan masalah pribadinya dan mendapatkan rasa aman (Latifa, 2017). Dalam hal ini, anak yang marah dan malas belajar perlu adanya komunikasi dengan orang tua mengenai apa penyebab anak marah dan menjadi malas belajar, sehingga dapat ditemukan solusi pemecahan masalahnya.

Apa yang terjadi pada perubahan psikologis ketujuh siswa selain pengaruh dari smartphone, orang tua juga memegang peranan penting dalam tumbuh kembang anak. Selaras dengan penelitian yang sudah dilakukan oleh (Rakhmawati, 2015) bahwa, keluarga merupakan satu hal terpenting dalam pengasuhan anak, sebab anak dibesarkan serta dididik oleh keluarga. Orang tua adalah gambaran yang dapat dilihat serta ditiru oleh anak dalam keluarga, oleh sebab itu pengasuhan anak merupakan kewajiban yang harus dilaksanakan oleh orang tua.

Dampak negatif dari penggunaan smartphone yang muncul pada anak seperti malas belajar dan suka meniru apa yang ada di smartphone memang merupakan suatu yang wajar dikarenakan secara psikologis anak usia enam sampai dua belas tahun senantiasa meniru apa yang mereka suka seperti video apa saja yang viral di Youtube, kata-kata yang keluar dari Gamers, maupun bahasa-bahasa yang tersebar di grup Whatapps. Kasus di atas serupa dengan temuan penelitian yang dilakukan oleh Widianto (2015) mengenai pengaruh teknologi terhadap pendidikan karakter anak. Hasil penelitian tersebut mengungkapkan bahwa anak meniru lagu dangdutan yang sering diputar di dalam rumah, perkelahian dari tontonan, dan juga perkataan yang kotor.

Dampak negatif di atas bisa diminimalisir melalui pengawasan orang tua, sehingga efek positif penggunaan smartphone di masa pandemi Covid-19 muncul seperti mencari materi pelajaran, tetap berkomunikasi dengan teman meski hanya sekadar via online. Efek positif lainnya menurut hasil penelitian yang dilakukan 
oleh Chusna (2017) seperti ditemukannya metode pembelajaran yang menarik yang bisa meningkatkan minat siswa untuk belajar.

\section{SIMPULAN}

Anak usia enam sampai duabelas tahun membutuhkan bimbingan dan pengawasan orang tua dalam mengoperasikan smartphone guna meminimalisir efek negatif yang ditimbulkan. Efek positif dan negatif samrtphone sangat tergantung dari penggunanya, dan perilaku anak sangat ditentukan dari peran orang tua dalam mengawasi tumbuh dan kembang anak. Dalam penelitian ini, anak yang menggunakan smartphone lebih dari 2 jam sehari dan tanpa pengawasan orang tua menimbulkan dampak negatif bagi psikologis anak terutama aspek emosional dan moral seperti mudah marah, malas belajar, meniru perilaku yang tidak berfaedah dan kecanduan bermain game online.

Penggunaan smartphone berkelanjutan juga memiliki dampak positif bagi psikologis anak terutama aspek sosial seperti anak tetap berkomunikasi dengan teman-temannya meskipun dalam masa pandemi Covid-19. Dalam rangka meminimalisir hal yang tidak diinginkan, orang tua hendaknya senantiasa mengingatkan kepada anak agar menggunakan smartphone sesuai dengan status dan kewajiban anak selaku siswa yaitu belajar. Maka anak boleh menggunakan smartphone setelah semua tugas sekolah selesai dikerjakan. Selanjutnya ketika anak menggunakan smartphone harus didampingi oleh orang tua baik langsung mengawasi maupun melalui jarak jauh dengan menyamakan akun gmail di smartphone anak. Bagi guru formal yang mengajar anak secara online disarankan untuk berkoordinasi dengan orang tua mengenai tugas yang diberikan dan perilaku yang nampak akibat penggunaan smartphone berkelanjutan di semester 2 masa pandemi Covid-19.

\section{DAFTAR RUJUKAN}

Afifulloh, M. (2019). Pemanfaatan Lingkungan Sekitar Sebagai Sumber Belajar Ilmu Pengetahuan Sosial. ElementerIs: Jurnal Ilmiah Pendidikan Dasar Islam, 1(1), 12-32.

As-Tsauri, M. S. (2021). Implementasi Metode Tami Otaka Dalam Pembelajaran Hafalan Al-Qur'an di TK PINTAR Kota Bandung. Jurnal Paedagogia, 10(1), 6784. https://doi.org/https://doi.org/10.24239/pdg.Vol10.Iss1.143

Ats-Tsauri, M. S., \& Munastiwi, E. (2020). Strategi Kepala Madrasah Dalam Menentukan Kebijakan Pembelajaran Era Covid-19: Studi Kasus Kepala Madrasah Ibtidaiyah NW Pondok Gedang. ElementerIs: Jurnal ILmiah 
Pendidikan Dasar Islam, 2(2), 55-61.

Chusna, P. A. (2017). Pengaruh Media Gadget Pada Perkembangan Karakter Anak. Dinamika Penelitian: Media Komunikasi Sosial Keagamaan, 17(2), 315-330.

Imam, A. (2019). Pengaplikasian Smartphone sebagai Media Komunikasi Interpersonal di Kalangan Pegawai Kementerian Agama Kabupaten Aceh Barat. International Journal of Islamic Studies and Social Sciences, 1(2), 343369.

Latifa, U. (2017). Aspek Perkembangan Pada Anak Sekolah Dasar: Masalah dan Perkembangannya. Academica: Journal of Multidisciplinary Studies, 1(2), 185196.

Palar, J. E., Onibala, F., \& Oroh, W. (2018). Hubungan Peran Keluarga dalam Menghindari Dampak Negatif Penggunaan Gadget pada Anak dengan Perilaku Anak dalam Penggunaan Gadget di Desa Kiawa 2 Barat Kecamatan Kawangkoan Utara. Ejournal Keperawatan (e-Kp), 6(2), 1-8.

Pradevi, A. P. (2020). Hubungan Pengawasan Orang Tua dalam Penggunaan Gadget dengan Kemampuan Empati Anak. Jurnal Pendidikan Anak, 9(1), 49-56.

Rakhmawati, I. (2015). Peran Keluarga dalam Pengasuhan Anak. Konseling Religi: Jurnal Bimbingan Konseling Islam, 6(1), 1-18.

Rozalia, M. F. (2017). Hubungan Intensitas Pemanfaatan Gadget dengan Prestasi Belajar Siswa Kelas V Sekolah Dasar. Jurnal Pemikiran Dan Pengembangan SD, 5(September), 722-731.

Sari, T. P., \& Mitsalia, A. A. (2016). Pengaruh Penggunaan Gadget Terhadap Personal Sosial Anak Usia Pra Sekolah di TKIT Al Mukmin. PROFESI, 13(2), 7278.

Suhandi, A., \& Pamela, I. S. (2020). Dampak Musim Libur Covid-19 Belajar dari Rumah Terhadap Psikologi Anak Sekolah Dasar. JGPD: Jurnal Gentala Pendidikan Dasar, 5(2), 207-218.

Syifa, L., Setianingsih, E. S., \& Sulianto, J. (2019). Dampak Penggunaan Gadget terhadap Perkembangan Psikologi pada Anak Sekolah Dasar. Jurnal Ilmiah Sekolah Dasar, 3(4), 527-533.

Widianto, E. (2015). Peran Orangtua dalam Meningkatkan Pendidikan Karakter Anak Usia Dini dalam Keluarga. Jurnal PG-PAUD Trunojoyo, 2(1), 31-39. 